\title{
有機燐製剮のフイルド実験について
}

\section{Field test of organic phosphorus insecticide}

\author{
藤 戶真 男 1 ) 武 衞和 雄1) 遠藤 斉 彦1) \\ 宅見竜雄 2 夏目俊夫2) 稲葉 祐 一2) \\ Sadao Fujito, Kazuo Buéi and Takahiko Endō \\ Tatsuo Takumi, Toshio Natsume and Yūichi Inaba
}

\section{I まえがき}

数とはえをなくする生活実践運動の 飛躍的発展につ れて各地に多大の成果をあげつつあるが，このばあいに いかに殺虫剂を効果的に用いるかによつてその成果が左 右されるものである，最近殺虫剤の野外実験を通じてそ の効力を評価しょ 5 とする研究業績が数多くみられるよ 万になつた ${ }^{1-3,6,8)}$. 衛生害虫の駆除にこれまで最も広く 用いられている殺虫㓮は DDT やリンデンなどの塩素系 合成殺虫剤で，地域によつてはこれらの殺虫剤に対する 昆虫の抵抗性の発達の問題がようやく論議されるように なつている. 最近有機燐製剤の発達にともない, 衛生害 虫駅除の面にも応用される機会が多くなりつつあり, ダ イアジノン, DDVP, Dipterex, マラッンなどが林販さ れるようになつた．これらの有機燐製剤を做いてはえや 敕を駆除寸るばあい，その効果や萝害などがいかに影響 するかを調查する目的で，われわれは大阪府下の一農村 においてフイルド実験を行つた，今回実験に用いた薬剤 はマラソンで, 粉末, 油剤, 乳剤拉の扔のの形態のもの を使用し，効力の比較検討をもあうせておこなつた。

この実験にあたり薬剤を供与していただいた住友化学 工業株式会社に対し，また作業実施にあたつて全面的協 力を仰いだ貝塚市役所衛生課の方々，ならびに地域住民 の方々に対し梁く打礼を申しあげる。

\section{II 実験地区の概況}

実験地区として選んだ貝塚市堤地区は，従来環境上の 施設改善が殆ど行われていない，かつ独立集落を形成し ている地域で, 戸数 100 戸, 人口 435 名の農村で, 農家 のほかに牛舎 12 力所, 養䳕舎 17 力所, 漬物工場 1 力所

1) 大阪府環境衛生課

Division of Insect and Rodent Control, Environmental Sanitation Section, Osaka Pref-Gov't.

2) 大阪府貝塚保健所

Health Center of Kaizuka, Osaka Prefecture.
織布工場 1 カ所がある. 周辺は水田にかこをれ, 部落の 西南部にかなり大きな用水池があつて, 池畔には厨芥な

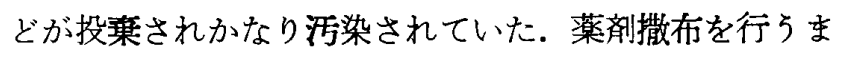
えにその対象となるべき蚊、はえの発生源について詳細 な調查を行つたところ表1のような結果がえられた。

また比較対照地区（薬剤無撒布地区）として堤地区と 距てて約 $1 \mathrm{~km}$ 南にある貝塚市地蔵堂を選んだ.この地 域は地理的にも部落の形態も実験地区と甚だよく似通つ たところで，戸数 70 戸，人口 400 名の独立集落をなし ている.

\section{III 実験方法}

実験供した薬剤は住友化学工業株式会社の製造によ るプレミアム・マラソンで, $1 \%$ 油㓮, $20 \%$ 乳㶡, 1.5 \%粉剤を実験に伐用した。

1. 薬剂の撒布法 家屋内, 納屋などに対しては油剤 を動力煙霧機によつて $33 \mathrm{~m}^{2}$ あたり $150 \mathrm{cc}$ の割合で撒 布し, 牛舎, 鵎舎, 便所に対しては乳剂を 50 倍（濃度 $0.4 \%$ ）に稀粎し，これを肩掛噴霧機によつて $1 \mathrm{~m}^{2}$ あた り $50 \mathrm{cc}$ の割合で壁, 天井，林などに充分に撒布した。 また便池，肥料溜，ごみ集皘場などに対しては乳剤を 400 倍(濃度 $0.05 \%$ ) 飞稀釈して $1 \mathrm{~m}^{2}$ おたり $2 l$ ，また は粉末を $1 \mathrm{~m}^{2}$ あたり $50 \mathrm{~g}$ の割合で撒布し，下水溝な どに対しては 400 倍に稀勫した乳剤を $1 \mathrm{~m}^{2}$ あたり 100 cc の割合で如露を用いて撒布した。 また竹やぶ，草む らなどの蚊の静止場所に対しては粉末を $1 \mathrm{~m}^{2}$ あたり 20 $\mathrm{g}$ の割合で撒布した.

この作業は 1958 年 8 月 3 日より開始し, 第 1 回目に は全家层や発生源などに対する撒布を行い, 以後 10 日, 17 日，24日，31日と7日毎に主として発生源や牛舎, 鷄舎, 家哐内の便所などに対して撒布した.

2. 効果判定の方法 判定にははえとりリボン, はえ とり瓶（砂糖を誘引餌とし，瓶中には米のとぎ汁をいれ た）およびフライグリル(一辺 $40 \mathrm{~cm}$ の木㱔)を用いた。 
(198) 衞 生 動 物 1959 年 Vol. 10 No. 3

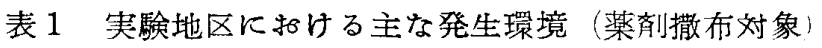

\begin{tabular}{|c|c|c|c|c|c|c|c|c|c|c|}
\hline 撒布対象 & 家 屋 & 納 屋 & 牛 舍 & 鶏 舍 & 便 所 & 肥料溜 & 下水溝 & $\begin{array}{l}\text { ごみ集 } \\
\text { 積場 }\end{array}$ & $\begin{array}{l}\text { 生垣, } \\
\text { 花弁, } \\
\text { 雑草等 }\end{array}$ & $\begin{array}{l}\text { 周辺の竹 } \\
\text { や占, 溝, } \\
\text { 雑草 }\end{array}$ \\
\hline 面 穓 $\left(\mathrm{m}^{2}\right)$ & 8254 & 1751 & 145 & 224 & $\begin{array}{c}\left(112^{*}\right) \\
271\end{array}$ & 7 & 248 & $\begin{array}{c}\left.2^{*}\right) \\
30\end{array}$ & 2492 & 133 \\
\hline
\end{tabular}

* 個所数

薬剤撒布区扣よび無撒布区よりそれぞれ牛含 3 力所，一 般家屋の台所 4 力所を任意に選定し，牛含に対してはは えとりリボンを，台所ではリボンとはえとり瓶を併用し て採集し，24時間ごとにとりかえて採集された数を記録 した。ささらに阿地区よりそれぞれ 3 カ所の牛舎を選び， また，薬剤撒布区のごみ集積場 2 力所を粉剂, 乳剂の各 撒布区にわけてフライグリルによる計測を行つた。これ は午後 4 時（土30 分）に拈のおのの場所に执いてフライ グリルを設置し，その上に 30 秒間に静止した数を記録 し，5回繰返しを行つて最高数をその日のはえ指数 (Fly index) とした.

3. 殺蛆実験 実験は乳剂と粉剂にわけ，乳剂による 実噭は一般家屋の便池 18 力所々肥料溜 3 力所を代意に 選んで行つた。すなわち乳㓣を水にて稀釈し，100倍（濃 度 $0.2 \%) ， 200$ 倍 $(0.1 \%), 400$ 倍 $(0.05 \%), 800$ 倍 $(0.025 \%) ， 1600$ 倍 $(0.0125 \%)$ の各濃度のものを各使 池や肥料溜に対し， $1 \mathrm{~m}^{2}$ あたり $2 l$ の割合で如露を用い て撒布し効力の比較を行つた。粉剤による実験では 12 カ所の便池について $1 \mathrm{~m}^{2}$ あたり $25 \mathrm{~g}, 50 \mathrm{~g}, 100 \mathrm{~g}, 200 \mathrm{~g}$ の割合で撒布した．効果の判定には約 $0.2 l$ 容量の杓 子を归い，糞侹を異る場所から 3 回採取して，これに水 を加兄て攪找しながら幼虫をふるい分け，ピンセットで これに触れても動かないるのを死亡とみなした。観察は 撒布の 1 日，2 日，4 日，7日後に行つた。肥料溜にお ける実験では, 薬剤撒布後の観察期間中に便の追加投大 はみられなかつた。

\section{IV 実験結果および考突}

1. はえとりリポン，はえとり瓶による効果制定 本 法によつて採集されたはえはイエバエが最も高い組成を 示し，その他の種類ではとメイェバェおよびキンバェ属 ニクバェ属数種のものが断続的に少数ずつとれているに すぎない. したがつてイエバェを判定の基淮とするのが 妥当であると思われる、はえとりリボンによつて，採集 されたイエバエの消長は两地区において明らかに暴つた 様相を示しているが，はえとり瓶のばあいでは両地区の 間において有意差は認められず，消長の様相が甚だよく 似ている，このことは，はえとり㼛に蝟集するはえがリ ボンの锡含とは全く暴つた反応のあらわれる結果である
と考えるべきで，リボンがはえの作息埸所として付着す る確率が高いのに対し，は学とり瓶のばあいではする䬧 に対して刺戟し，走化性によつて蝟集したものが捕隻导 れるという特定の方法であつて, 全く偶然の機会に支配 されやすいとい5結果によるものと考光られる。しえが

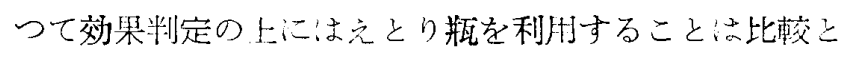

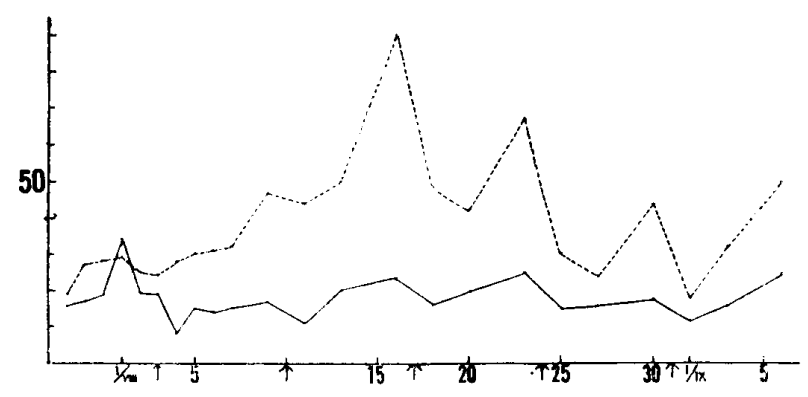

図 1 アラソン撒有区 $($. の屋内台所に扣けるイエバェの消長の比較 はえとりリボンによる)

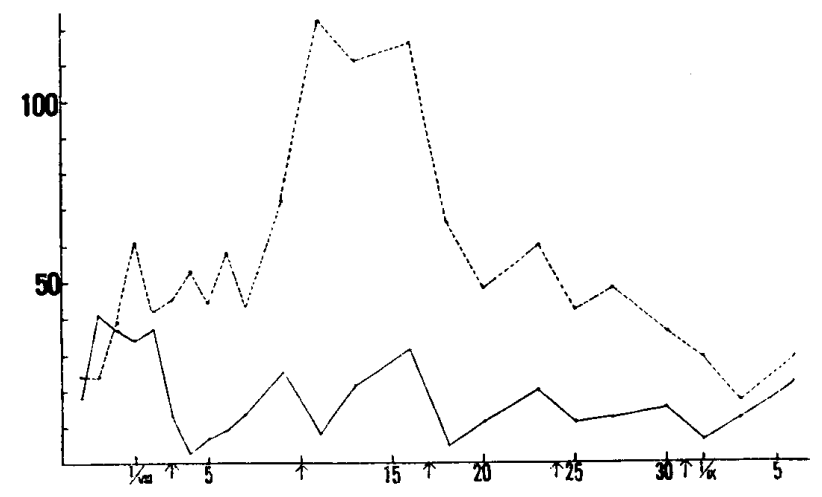

図2 マラソン撒布区之無撒布区の牛舎に扣ける イェバェの消長の比較（はえとりリボンによる）

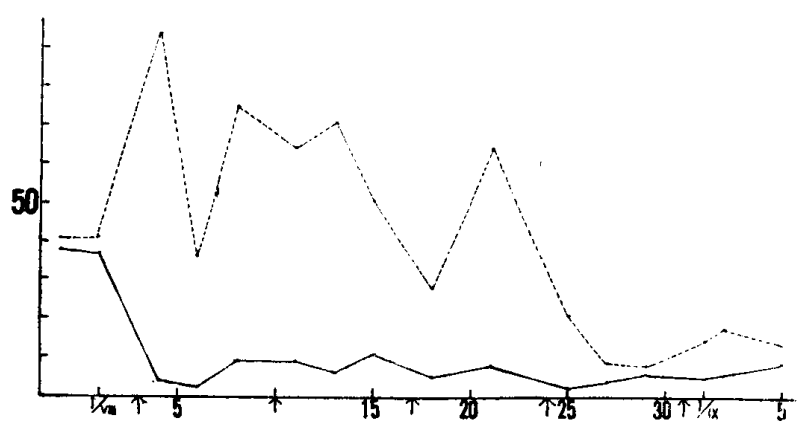

図 3 マランン撒布区と無撒布区の牛舎に扣け るイエバエの消長の比較(フライグロルによる) 


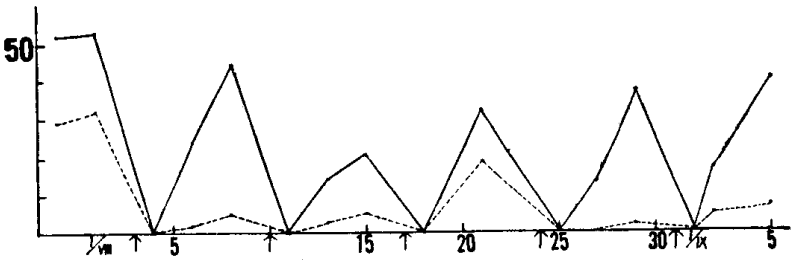

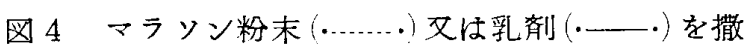
布したごみ集積場に扣けるはえの消長の此較

(フライグリルによる)

いう点からは不適当であるといわなければならない。

はえとりリボンによる牛舎および台所に拈けるイエバ エの消長は図 1 および図 2 に示したとおりで，薬剤撒布 区と対照区の間において明らかに晎つた成績を示し，薬 剂撒布区におけるイエバェの顕著な減少がみとめられ る.第 1 回目のマランン撒布を行つた 8 月 3 日以前の消 長は兩地区間に大きなひらさはあらうれていないが，撒 布後は阿地区の梯相が全く相離反している。牛含ではマ ラソンの撒布を 7 日後に行つているが, 台所, 牛舎とも 実験期間中に活動の回復はみられず，対照区において顕 著なピークを示す 8 月 15 日前後においても撒布区では 著しくその活動が抑制されていることがわかる. 平社 ら は豚舎に対し $1 \%$ malathion 乳剤を $1 \mathrm{~m}^{2}$ あたり 80 cc 撒布したとき，撒布後 1 週間あまりは減少し，そつ 後徐々に増加すると報告したが，著者らの牛舎に抢ける 成績ではそれよりも低濃度で著しい効果を示しているこ とになる．地域全体にわたつて駆除作業が徹底すれば， 薬刜の䟴度や撒布量が少いばあいにもかなり効果をあげ 万るものと思われる。

2. フライグリルによる効果制定 野外実嘘にフライ グリルを用いて效果を判定する方法は最近かなりその㬰

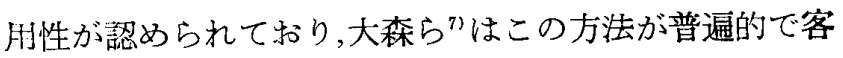
観性をるち，リボン等と比較してその判定がとりやすい ことをとりあげている。フライグリルに静止するはえは 牛含，ごみ集積場ともイエパエが大部分であつた。牛舎 に护る成績は図 3 に示したと拈りで，リボンの成續と 同様にマラソン撒布後の両地区の様相が明らかに異つて いる. また 2 力所のごみ集積場に拈いて粉剤, 乳剤の备 撒布区に捈ける成績は図 4 のと扣りである。撒布は7日 毎に行つているが，撒右後 1 日目の調查では粉剤，乳剤 いずれのばあいに括いても全くはえは消失している.し かし乳剤撒布区では次回の撒布までに活動の回復が比較 的早く，それと較べて粉剂を用いた方が効果の持続性が 大きい、ごみ集積場のようなリボンやトラップを批いて

表 2 乳剂による殺蛆実験成績（便池）

\begin{tabular}{|c|c|c|c|c|c|c|c|c|}
\hline \multirow{2}{*}{ 稀釈 濃度 } & \multicolumn{4}{|c|}{ 実 験 場 所の 条件 } & \multicolumn{4}{|c|}{ 撒布後の成績 } \\
\hline & 便 量 & 便の硬軟 & $\begin{array}{l}\text { 落し紙の } \\
\text { 奖況 }\end{array}$ & $\begin{array}{l}\text { 幼虫の成 } \\
\text { 育状態 }\end{array}$ & 1 日後 & 2 日後 & 4 日後 & 7 日後 \\
\hline \multirow{3}{*}{$\begin{array}{l}0.2 \% \\
(100 \text { 倍 })\end{array}$} & 中 & 軟 & 中 & 大, 中 & - & - & + & $H$ \\
\hline & 中 & 軟 & 中 & 大, 中, 小 & - & - & - & - \\
\hline & 中 & 中 & 少 & 小 & - & - & + & H \\
\hline \multirow{3}{*}{$\begin{array}{l}0.1 \% \\
(200 \text { 倍) }\end{array}$} & 中 & 軟 & 中 & 大, 中, 小 & - & - & - & - \\
\hline & 多 & 軟 & 少 & 大, 中, 小 & - & - & + & $H$ \\
\hline & 中 & 軟 & 少 & 中 & + & - & + & $H$ \\
\hline \multirow{6}{*}{$\begin{array}{l}0.05 \% \\
(400 \text { 倍) }\end{array}$} & 中 & 軟 & 少 & 大 & - & + & - & - \\
\hline & 少 & 軟 & 少 & 大 & - & - & + & $H$ \\
\hline & 多 & 軟 & 少 & 大, 中, 小 & + & - & $H$ & $H$ \\
\hline & 中 & 軟 & 少 & 大, 中 & 一 & - & + & $H$ \\
\hline & 少 & 中 & 少 & 大, 中 & 一 & - & + & $H$ \\
\hline & 多 & 軟 & 少 & 大, 中 & 一 & - & - & $H$ \\
\hline \multirow{3}{*}{$\begin{array}{r}0.025 \% \\
(800 \text { 倍 })\end{array}$} & 多 & 中 & 少 & 大, 中, 小 & + & - & + & $H$ \\
\hline & 中 & 軟 & 少 & 大, 中 & - & - & + & $H$ \\
\hline & 中 & 軟 & 少 & 大, 中 & + & + & $H$ & H \\
\hline \multirow{3}{*}{$\begin{array}{r}0.0125 \% \\
(1,600 \text { 倍 })\end{array}$} & 少 & 軟 & 少 & 大, 中 & + & - & - & $H$ \\
\hline & 多 & 軟 & 少 & 大, 中 & $\mathrm{HH}$ & $H$ & $H$ & $\mathrm{HH}$ \\
\hline & 多 & 中 & 少 & 大, 中 & + & - & $H$ & $H$ \\
\hline
\end{tabular}

備考 $\mathrm{H}$ 全部生存

$H^{1} 1_{2} \sim 1 / 3$ が生存 + 殆んど死亡しているが少数が生存 
表 3 乳昘による殺蛆実験成績（肥料溜）

\begin{tabular}{|c|c|c|c|c|c|c|c|}
\hline \multirow{2}{*}{$\begin{array}{l}\text { 稀釈濃 } \\
\text { 度 }\end{array}$} & \multicolumn{3}{|c|}{ 実験場所の条件 } & \multicolumn{4}{|c|}{ 撒布後の成績 } \\
\hline & 便量 & $\begin{array}{l}\text { 便の硬 } \\
\text { 軟 }\end{array}$ & $\begin{array}{l}\text { 幼虫の } \\
\text { 战育状 } \\
\text { 態 }\end{array}$ & 1 日後 & 2 日後 & 4 日後 & 7 日後 \\
\hline $0.1 \%$ & 多 & 軟 & 大 & + & 一 & - & - \\
\hline (200倍) & 多 & 軟 & 大 & $H$ & 一 & - & 一 \\
\hline \multirow{3}{*}{$\begin{array}{l}0.05 \% \\
(400 \text { 倍) }\end{array}$} & 多 & 軟 & 大 & 一 & - & - & - \\
\hline & 多 & 軟 & 大 & - & - & - & - \\
\hline & 多 & 硬 & 大 & - & - & - & - \\
\hline
\end{tabular}

められなかつた，実験期間中にこれらの肥料溜に健の追 加投入が行われなかつたことから考えあわせると，肥料 溜における二次的な発生は案外少いものと考兄られよ ら。また粉剤の便池にお汸る効果は， $1 \mathrm{~m}^{2}$ あたりの撒 布量が $25 \mathrm{~g}$ のばあいにも撒布值後においては影著な効 果が認められた．しかし $100 \mathrm{~g}$ 以上撒布すると 7 日後に おいても全く発生は俧められなかつたが，50 g 以下のば あいは 4 日後より再び発生が認められた。

以上の結果を総括すると, 便池に拗いては乳剤は稀稂 濃度 $0.025 \%$ まで, 粉㓮では $1 \mathrm{~m}^{2}$ あたり $25 \mathrm{~g}$ で効力が

表 4 粉剂による殺蛆実験战績（便池）

\begin{tabular}{|c|c|c|c|c|c|c|c|c|}
\hline \multirow{2}{*}{$\begin{array}{c}1 \mathrm{~m}^{2} \text { 出えり } \\
\text { 撒布量 }\end{array}$} & \multicolumn{4}{|c|}{ 実験場所の条件 } & \multicolumn{4}{|c|}{ 撒布後の成績 } \\
\hline & 便 量 & 便の硬軟 & $\begin{array}{l}\text { 落し紙の } \\
\text { 状況 }\end{array}$ & $\begin{array}{l}\text { 幼虫の成 } \\
\text { 育状態 }\end{array}$ & 1 日後 & 2 日後 & 4 日後 & 7 日後 \\
\hline \multirow{3}{*}{$200 \mathrm{~g}$} & 少 & 軟 & 少 & 大 & - & - & - & - \\
\hline & 多 & 中 & 少 & 中, 小 & - & - & - & - \\
\hline & 中 & 軟 & 少 & 小 & - & - & - & - \\
\hline \multirow{3}{*}{$100 \mathrm{~g}$} & 中 & 中 & 少 & 中, 小 & - & - & - & - \\
\hline & 少 & 中 & 少 & 大, 中, 小 & - & - & - & - \\
\hline & 少 & 軟 & 少 & 中, 小 & - & - & - & - \\
\hline \multirow{3}{*}{$50 \mathrm{~g}$} & 中 & 軟 & 少 & 中 & + & - & + & $H$ \\
\hline & 多 & 軟 & 少 & 大, 中 & - & - & $H$ & $H$ \\
\hline & 中 & 中 & 少 & 大 & - & - & H & $H$ \\
\hline \multirow{3}{*}{$25 \mathrm{~g}$} & 多 & 軟 & 少 & 大, 中 & - & - & $H$ & $\mathrm{HH}$ \\
\hline & 多 & 軟 & 少 & 中, 小 & + & - & $H$ & H \\
\hline & 中 & 軟 & 少 & 大, 中 & + & + & $H$ & $H$ \\
\hline
\end{tabular}

効果を判定しがたい環境においては，フライグリルを用 いると比較的容易に評価できるよ5に思われる。

3. 殺蛆実験 マラソン乳剤の各稀譒濃度に括ける実 験成績は表 2 , 表 3 に, 粉剤の単位あたり撒布量のちが いにもとづく実験成績は表 4 亿示したと扮りである。乳 鼡の便池に扝ける成績では $0.025 \%$ の濃度まで撒布後の 効果が充分認められるが，撒布 4 日後から再び発生しは じめ，7日後には撒布前の状態近くなつている，同様 な成績は千葉県に拁ける実験においてオルソ剤やリンデ ン乳㨈のばあいにも認められる ${ }^{11}$ 。た $0.0125 \%$ の濃度 では実験の便池沉つて差があらわれているが，殺蛆効 果はかなり小さくなるものと考兄られる，以上のことか ら，乳剤の稀䣋効果の账度は $0.025 \%$ あたりにあると思 われるが，残効性は此較的短かく，少くとも最盛期にあ つては毎週 1 回は撒布する必要がある。肥料溜に打ける 成績によると，乳剤の稀釈濃度 $0.05 \%$ に扣いても完全

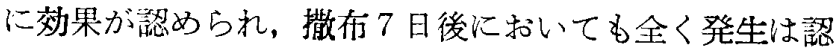

あらわれるが，少くとも7日以上の効果の持続性を期待 するためには粉剤 $100 \mathrm{~g}$ 以上を撒布することがのぞまし いまをた肥料溜に対しては，一回の撒布によつて少くと も侹の追加投大が行われない煺り発生はみられないもの と考完られる。

本撒布実験により家屋内あるいは牛舎，鷂舍などに撒 布を行つたときに，人体むるいは家畜などに対する薬共 は全くあらわれないことが竐明された。

\section{$\mathbf{V}$ まとめ}

1. 大阪府下の一農村に括いてマラッンの粉末, 油剤, 乳剤の各形態のものを䏳いてフイルド䒠験を行つた。

2. 効果の判定にははえとりリボン，フライグリルを 打いたが, 屋内台所, 牛舎に叔けるイェバェの消長は対 照地区(薬剤無撒布地区) との閒に明膫な美があらわれ， 撒布地区に打ける顕著な減少がみとめられた。

3.ごみ集積場においては粉末撒布のばあいに効果の 
持続性が大きい。

4. 便池におけるはえ幼虫駆除の効果は, 乳剂では稀

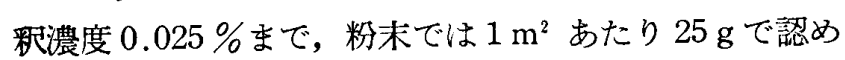
られたが，7 日以上效果の持続性を期待するためには粉 末る $100 \mathrm{~g}$ 以上撒布する必要がある。また肥料溜に対し ては，1回の撒布によつて便の追加投大が行われない限 り発生はみられないるのと考えられる.

\section{参考文. 献}

1) 千葉県環境葦生課・八日市場保健所・八日市場市 役所 $(1957)$ : 生活々環境, $2(8): 15-26 .-2)$ 千葉 県環境衛生課・木更津保健所 - 小匮村 (1957) : 生活 と環境, $2(11)$ : 37-39. 一3) 千葉県環境噟生課・木 更津保健所・袖ケ浦町 (1958)：生活と環境, $\mathbf{3}(1)$ : 43-47. -4) 平社俊之助 - 本田博 - 福井正信 - 長田 泰博 $(1957)$ : 葦生動物, 8(3) : 179-181. -5) 平社 俊之助・本田博 (1958)：衛生動物，9(1)：55-59. 一 6) 喜島功・藤江正二・二見晃・金田勇 $(1957)$ : 生活 と環境，2(1)：22-25，-7）大森南三郎・末永斂・ 大利茂久 - 福田通男 - 谷川十三生 $(1958)$ : 得生動物, $\mathbf{9}(2)$ : 89. 一8) 椎名実 (1958)：生活々環境, $3(4)$ : 38-41.

\section{Summary}

1. The field tests of oil solution, emulsion and dust of malathon (malathion) were carried out at a rural district in Osaka Prefecture.

2. The fly-ribbon and the fly-grill were employed for the decision of the efficiency of the insecticide. The distinct decrease of house fly population were shown at the kitchen, the room of the live stock compared with the control district.

3. The residual efficiency of dusting at the dump was more continuous among all others.

4. The control efficiency on larvae in the toilet pool are as follows, the efficiency were shown with the emulsion (up to $0.025 \%$ ) or dusting (arround 25 grams per $\left.1 \mathrm{~m}^{2}\right)$, but for expecting more than 7 days' efficiency, it was necessary more than 100 grams per $1 \mathrm{~m}^{2}$ of dusting.

In the cess pool, the larvae do not growing up by once dusting without following throw of faeces.

\title{
同一楽量の高濃度部分処理と低濃度全面処理の イエバエ成虫に対する効力の比較について
}

\author{
Comparison of effects of insecticidal residues on house fly \\ by narrower surface application in higher dosage with \\ those by wider surface application in lower dosage
}

\author{
平 社 俊之助2 \\ Shunnosuke Hirakoso
}

\section{まえがき}

殺虫剤は，その使用方法または適用方法によつて效力 が変つて来ることが知られている.

1) Strip 法によるハェ駆除の研究 2

2) 東京大学伝染病研究所寄生虫研究部 (部長 : 佐々 学教授)

Department of Parasitology, Institute for Infectious Diseases, University of Tokyo (Chief: Prof. M. Sasa.)

中央化学株式会社

Chuo Kagaku Co., LTD.
本報においては，同一薬量を狭い部分に重点的に処理 した時と低濃度にて広く処理した時，その効力がどのよ 丂に変つて来るかを，イエバェ成虫を用い堂内的に，そ の初期效果及び残留効果の両面より検討を加えたもので ある。

な初本実験を行うに当り御指道下さつた部長佐々学教 授, 御稿正たまわつた鈴木猛博士, 室員の皆さまに厚く 御礼明し上げます。

\section{供試昆虫}

イェバェ成虫 Musca vicina Macquart： DKM-strain, 